\title{
The Importance of Involving Community Organizations for Preventing Destructive Fishing Activities in Mannar, Sri Lanka
}

\author{
S. S. M. Peramunagama ${ }^{\mathrm{a}, *}$ and R. Thusyanthini ${ }^{a}$ \\ a Department of Agriculture, Kilinochchi 44000, Sri Lanka
}

Email Correspondence: swarnamalitha@gmail.com (S. S. M. Peramunagama)

Received: 17 March 2021; Revised: 19 April 2021; Accepted: 1 May 2021; Published: 31 May 2021

\begin{abstract}
The irresponsible destructive fishing practices with respect to the ecosystem approach have remained a major concern since the elimination of these practices has not been easy despite efforts. There is an urgent need to identify the different types of destructive fishing methods and their threats to fisheries then, to assess how the different organizations/groups/individuals confront with these threats. This study was carried out in Pesalai, a fisheries village in the Mannar district of Northern Sri Lanka in the years 2016 and 2017. The methodology employed consists of a pre-tested structured questionnaire in the field survey with a random sample of 310 fishers and a focus group discussion was conducted where 20 fishers actively participated. The results revealed that trawling net fishing, dynamite fishing, brush pile fishing, and stake net were being used extensively by the fishers. However, the use of such gears have facilitated to catch more fish and earning a high income. Resultant, the major negative impacts were gearing damages, nets damages and net loss. It is apparently found that, the majority of fisheries (93\%) had faith in fisher community organizations (fisheries co-op society, the church/father and women welfare society) in terms of resolving conflicts which were raised by destructive fisheries (wrangling, argument and dissension) while $7 \%$ of the respondents have faith in the state to resolve conflicts. The fisheries believed that, the government supports for fishing activities was not well required. Hence, it is strongly concluded that the Regulations should be enforced, as a joint effort between the department of fisheries and community organizations.
\end{abstract}

Keywords: Destructive fishing methods, Mannar district, Northern Sri Lanka 


\section{Introduction}

Improving the fisheries production is vital for reducing starvation and poverty for people in the Northern Sri Lanka. Sustainable, fruitful fisheries improve nourishment and food securities, which increase income and fisheries' livelihoods, protect the environment and natural resources and promote economic growth [1]. Fisheries sector is the major income source of the Mannar district's population. According to Asha et al [2] were from 36 fishing villages, 14,990 fishing families are. In terms of fishing population, it is 17,540 . Approximately $48 \%$ of the district's population in the year 2017. A sustainable approach to fisheries helps to protect our natural resources and make sure the fish stock is available for future generations. Currently, the technological changes, increase use of destructive fishing practices, management practices, development of the industrial sector and agricultural effluence, trigger the decline of fish stocks [3].

The fisheries sector is an essential economic element for people of the Mannar district in the Northern of Sri Lanka [4]. This sector has been affected for the last three decades by an ethnic civil war [5]. The local economy had been badly affected by internal and international displacement, loss of property, including fishing gear and infrastructure facilities, and loss of life [2]. With the lifting of a ban on fishing after the civil war in 2009, Mannar fishing communities appreciated the Government of Sri Lanka for their consideration on them. As a result, a large number of fishermen ventured into coastal fishing practices, and which significantly improved the income of fisheries sector. On the other hand, it could be said a major milestone for the fishing sector in the postwar scenario. However, while there is a hope of restoration of normalcy in their daily lives, fishers have also had to deal with the threat of destructive fishing activities in their fishing grounds [6]. In order to lead to prosperity, the Sri Lankan fishing industry needs proper management. Hence, one or more vital components of an ecosystem are losing the ability to provide essential ecosystem functions [3]. The term 
"destructive" is used to indicate techniques that are environmentally unfriendly, thus it can damage the ecosystem and lead to depletion of resources such as many marine resources, especially coral reefs, mangroves, mammals, and endangered species by fisher stakeholders, fishing community leaders, and other community organization officers. Therefore, presence of formal agreement on this term in terms of national laws and permits, certainly prohibits certain types of destructive techniques or practices [7][8].

This paper discusses some of destructive fishing methods were used, and how different organizations/groups/individual copes with these threats.

\section{Methodology}

This study was conducted in Pesalai, Mannar, Sri Lanka in the years 2016 to 2017. Pesalai is a predominantly fishing and farming village, which situated in Mannar district, Northern province of Sri Lanka. The primary data collection methods were direct field observation, focus group discussions, interviews with affected fishers and a pre-tested structured questionnaire also were used in the field survey with a random sample of 310 fishers. For focus group discussion (FGD) 20 fishers were selected and Participatory Rural Appraisal techniques such as pairwise ranking and venn diagram were used to obtain information. In detail, the participants were requested to list out the organizations/institutions/groups which were in their village or on the other hand, which were located somewhere else but provided services to cope with the destructive fishing methods. Then, time was given to discuss among the participants and rank the organizations according to the services of organizations which were needed to satisfy their needs. During an interview with affected fishers, the data regarding socio economic characters, diverse fishing techniques, their opinion towards different types of fishing techniques, conflicts with respect to practicing different fishing techniques and mechanisms for conflict resolution.

Further, the following secondary data namely, institutions' hierarchy, 
role in terms of fishers' livelihood, chain of command and fishers' partnership with the institutions were collected from the relevant institutions, such as Fishermen co-operative societies, women welfare society and Rural development society.

\section{Results and Discussion}

In Accordance with the basic socio-demographic characteristics of the questionnaire survey sample, the majority (83\%) of the fishermen were middle aged (18-55years) who constituted the economy (main livelihood) while 17\% were elder (over 55 years old). Regarding the level of formal education (years), the mean value was $8^{\text {th }}$ grade. Where people were with lack of awareness of the impacts of destructive fishing. Due to this, fishers contributed and depended on destructive fishing methods. Meanwhile, people had a lack alternative income source in Pesalai except fishing According to the years of experience in fishing where at least one person per household employed full time, analysis showed that, the fishers had 22 years mean year of experience. Noticeably they were affected by any of destructive fishing methods which they practiced.

Although fishing harbor and landing sites are essentially the entire Mannar coast didn't have both. Resultant, all fiberglass boats and other traditional boats (wallam and theppam) landed on the beach while trawlers and multi-day boats were anchored in the sea. In comparison with the expense of the fishermen, middlemen earned unjust profits. Furthermore, insufficient ice use, unsatisfactory handling of fish, poor processing facilities and other issues were impacting on the quality deterioration of the caught fish.

The following fishing gear methods/ techniques (Table 1) were identified to be "destructive" from semi-structured interviews and focus group discussions. 
Table 1: The extent of use of destructive fishing techniques

\begin{tabular}{|c|c|c|c|c|c|c|c|c|c|c|c|c|c|c|}
\hline $\begin{array}{l}\text { Fishing methods/ } \\
\text { techniques/ gears }\end{array}$ & 1 & 2 & 3 & 4 & 5 & 6 & 7 & 8 & 9 & 10 & 11 & 12 & $\mathrm{~T}$ & $\mathbf{R}$ \\
\hline 1.Use of dynamite & $X$ & 1 & 1 & 4 & 1 & 1 & 1 & 1 & 1 & 1 & 1 & 1 & 10 & 2 \\
\hline 2.Use of brush pile & & $x$ & 2 & 4 & 2 & 2 & 2 & 2 & 2 & 2 & 2 & 2 & 9 & 3 \\
\hline 3.Use of stake net & & & $x$ & 4 & 3 & 3 & 3 & 3 & 3 & 3 & 3 & 3 & 8 & 4 \\
\hline $\begin{array}{l}\text { 4. Local trawling } \\
\text { nets }\end{array}$ & & & & $x$ & 4 & 4 & 4 & 4 & 4 & 4 & 4 & 4 & 11 & 1 \\
\hline 5.Crabs net (Trap) & & & & & $x$ & 5 & 7 & 5 & 9 & 5 & 5 & 5 & 5 & \\
\hline 6.Disco net & & & & & & $x$ & 6 & 8 & 9 & 6 & 6 & 6 & 4 & \\
\hline 7.Trawling net & & & & & & & $x$ & 8 & 9 & 10 & 11 & 12 & 1 & \\
\hline 8.Dragging net & & & & & & & & $x$ & 8 & 10 & 11 & 12 & 3 & \\
\hline 9.Gill net & & & & & & & & & $x$ & 10 & 11 & 12 & 3 & \\
\hline 10.Long line & & & & & & & & & & $x$ & 11 & 12 & 3 & \\
\hline 11.Sooda net & & & & & & & & & & & $x$ & 11 & 5 & \\
\hline 12.Maduwa net & & & & & & & & & & & & $x$ & 4 & \\
\hline
\end{tabular}

(T: total, R: rank)

Source: Focus Group Discussions -Pesalai in 2016, Tool: Pair Wise Ranking

The given table 1 presents destructive fishing methods and then which were pair compared based on the severity.

\section{Local Trawling Net}

Resultant, trawling nets were large nets which were used to catch ground fish and other commercially targeted fish and crustacean species. Therefore, trawling net was ranked first because of most destructive fishing gear types which directly threatened species richness and biodiversity (there were around 100 boats with trawling net in Pesalai). Other than that, they caught a variety of non-target, undesirable or unmarketable species. The non-target species, or bycatch, often discarded overboard either dead or dying. Some fisheries, the bycatch could be large. Every pass of a local trawler (with trawling net) crushed corals and some being more than hundred years old. The trawlers destroyed the seabed in the north and south of Mannar these days, while 
sweeping the bottom of the sea. Aquatic creatures were swept away by this kind of trawl net fishing, affecting the catch of non-trawl fishing methods [9]. In addition, trawling net has destroyed the drift nets of local fishermen and could seriously damage small boats and nets ( 15 incidents were recorded). This mostly occurred during night because trawl boats failed to observe the long, and it is invisible gill nets. And most commonly deployed by local fishers [10]. Other measurable negative impacts of trawling net were on valuable fishing gear and net of around 25 local fishermen which restricted them to fewer days for fishing and a much reduction of income.

\section{Dynamiting}

Dynamiting was ranked as the second severe constraint. This explosive was used to kill fish because dynamite was easy and cheap. Hence fishers simply made dynamite/homemade bombs by using locally available ingredients. The fishes are killed by the shock of the explosion and then removed from the surface or collected from the bottom. The explosion killed a large number of fishes and other marine life in the vicinity and could damage the physical environment. In count, use of dynamite damaged the gill nets of local fishermen (23 incidents were recorded). Explosive fishing is illegal in many waterways globally. In Sri Lanka, this was being practiced throughout the country [11]. Resultant, it killed fishes rapidly and imbalanced healthy ecosystem. Therefore, dynamiting is considered as one of the most destructive techniques used by fisheries. It was strongly believed that dynamiting was also practiced by outsiders, while the local fishers were widely actually practiced. The Fisheries Inspectors often claimed that there were many practical difficulties to take action against fishers who used dynamiting. The fishermen using dynamite should be caught. The meantime, it should be proved that fish is caught by using dynamite. Another difficulty in enforcing the law was the high degree of political intervention that led to release the arrested fishers because of dynamiting. 


\section{Brush Pile Fisheries}

The negative impacts of Brush pile fisheries were thirdly ranked. Which showed the fishing technique cut mangrove branches and then these were put in lagoons to aggregate fish. Fishing was done with small piles surrounded by a net, then removed all the branches and followed the mesh. The nearby net met step by step netting for the bigger brush parks, as the branches were removed up to the high-density fish's area and thus traps, baskets and hand nets could be removed. After fishing, the used branches were swapped, and new ones added based on necessity. Approximately $65 \%$ of the fishermen attributed that, this practice was negatively, significantly impacting on mangroves in northern Sri Lanka. Since mangrove environments were essential component for fish breeding, due to mangrove destruction, this noticeably led to depletion of fish resources. Other than that, Brush pile fisheries demolished number of gill net (11 incidents were recorded) and had damage to fiberglass reinforced plastic boats (7 incidents were recorded) because the location of the brush pile will only be familiar to the user, the damage can occur when other fishermen enter the same location.

\section{Stake Net (Wing Net)}

Stake net was ranked fourthly, which was a net held in position by stakes. It was fixed in the ocean by using metal pipes. However, the stakes used at present were long PVC which were harmful in many ways: To fix these in the seabed, the seabed was dug intensively, and it was like a large fence, where a floating gill net also entangled in a stake, but the net mostly got loose (17 incidents were recorded) and it was threatening to maneuver. Probability to damage small crafts were high with iron bars (6 incidents). Disappointingly, in Southern Mannar, the modern net was increasingly popular. Hundreds of these nets were placed recently, about ten kilometers of sea was fenced in this fashion from the South Bar beach up to Pesalai Coral Reefs, with small scale fishermen and beach seiners became increasingly obstructed by this new destructive and dangerous fishing method. 
The use of destructive fishing gear was widespread in the study area and most fishermen worked as laborers with few entrepreneurs who owned fishing gears and socio-cultural factors that influence gear choice. Some destructive fishing techniques (trawling net and monofilament net) led to excessive catching and juvenile wastage that threatens sustainability of fishery. Wastages of juveniles were not given a chance to breed and recruit into the fishery. Therefore, destructive fishing methods impacted not only on target resources, but also on nontarget species and wider aquatic environment. From the survey, about $91 \%$ of the fishermen attributed fish catches were being declined by use of destructive fishing gears. In accordance with use of dynamite in coral reefs, severely damaged habitats and which may take several decades to recover completely. Particularly, fishermen also lost their arms due to the use of dynamite in Pallimunai area.

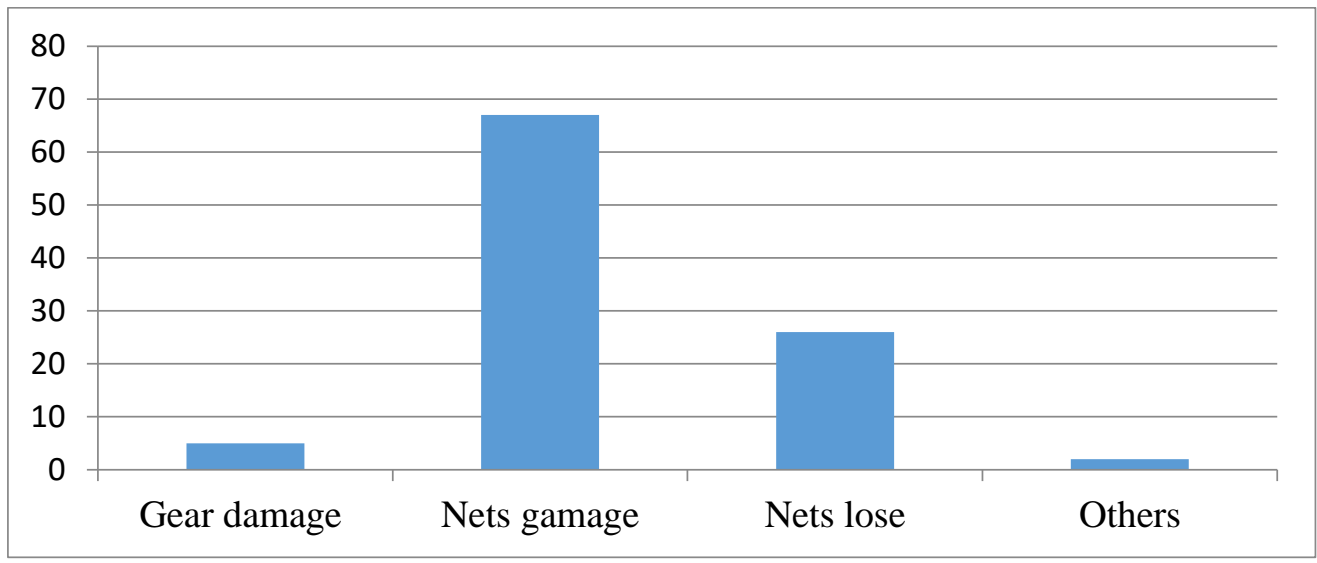

Figure 1: Number of incidents (Impact) on destructive fishing methods in 2016-2017

The presented bar chart enumerates the information on the impacts of using destructive fishing methods during 2016-2017. Resultant, the following negative impacts were recorded, gear damage, nets damage, net loss, and other incidents (disturb to community peace, mental stress and ratiocination). In comparison, nets damage and net losses were highly affected by approximately $67 \%$ and $26 \%$, respectively, while gear damage and other incidents were less than five percent. 
In Sri Lanka, even though department of fisheries play key role in fisheries resources, the department does not have adequate surveillance capacity. For an example, the use of numerous destructive fishing gears such as dynamite and trawling fishing and stake net with iron rods were banned by department. But they do not have adequate resources for surveillance (specially there is no procedure) [2]. One of the major reasons for it, the department does not have adequate financial resources. In other word, there is no proper resolution due to limited budgetary allocation of investigation and officials in various sites had no means of patrolling of jurisdiction to rely on the good will of the fishers. Therefore, it is important for the department to be empowered with adequate staff and financial resources that could enable them to frequently visit where most of the destructive fishing gears are being used. In addition, there is an urgent need to increase the number of village fish scouts and fisheries officers so that they will be able to cover most of the fish landing beaches to manage what is landed.

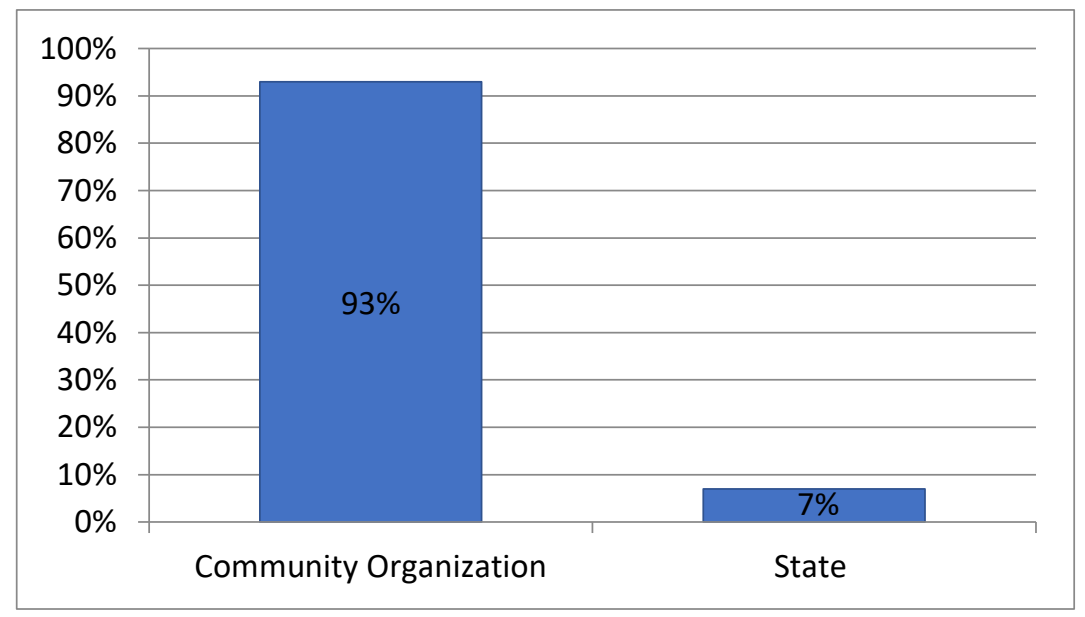

Figure 2: Conflict Resolution Mechanisms in the Northern Fisheries

The respondents were requested, which institution they had faith capacity to resolve conflicts. These are given in the figure 2 . Apparently, most fishers $(93 \%)$ had faith in fisher community organizations in resolving conflicts while $7 \%$ of the respondents had faith in the state, this shows the importance of community-based fisheries organizations in 
terms of resolving conflicts among stakeholders. According to Peramunagama [12] it was highlighted that there were two parallel fisheries community organizations in North (in the country as a whole); one was age old fisheries cooperatives and other one was recently established. This is rural fisheries organizations. In accordance with both field observations and key informant discussions, the fisheries cooperatives remained the dominant form of fisheries community organizations, while the rural fisheries organizations had a political tone and was often remain dormant. Most households surveyed showed because of unsatisfactory supports of government, fishers had negative perceptions towards them. Furthermore, around $80 \%$ of the interviewees stated that There were conflicts among fishers and government sectors, therefore, their preference for adopting certain gear types were not addressed by the current fisheries' management regimes. In other word, $99 \%$ of the participants discussed that although government agenda said about destructive fishing practices particularly, dynamite fishing these were very unclear to understand Moreover, the participants indicated that government paid little attention about impacts of destructive fishing methods when compared with other aspects related to the misuse and degradation of natural resources (such as illegal logging and poaching of wild animals).

For instance, Fisheries Cooperative society was ranked first based on the benefits which were received by fishers while the interaction between them was ranked secondly. This clearly indicated that though the people got good services from fisheries Cooperative society, accessibility was somewhat low. Most of the time many incidents were commonly related to the user of destructive fishing practices or among persons or groups created by disagreement and sentiment, where community relationship is broken or missing finally, then which created conflicts. Conflict played a negative and destructive role in the process of organizational development. To overcome or resolve the conflict, there was a need for adaptation. 
Table 2: Benefits and interaction of organizations for villagers (Venn diagram)

\begin{tabular}{lcc}
\hline Name of the organization & $\begin{array}{c}\text { Rank according to } \\
\text { the benefit of the } \\
\text { organization }\end{array}$ & $\begin{array}{c}\text { Rank according to the } \\
\text { interaction with the } \\
\text { villagers }\end{array}$ \\
\hline $\begin{array}{l}\text { 1.Fisheries Cooperative } \\
\text { society }\end{array}$ & 1 & 2 \\
2.Women welfare society & 2 & 3 \\
3.Church/Father-R C & 8 & 1 \\
4.Government Re & 6 & 10 \\
development project & 3 & 6 \\
5.Rural development society & 5 & 5 \\
6.Elders development society & 7 & 8 \\
7.Church/Father-non RC & 10 & 4 \\
8.Police & 9 & 7 \\
9.NEVI & 5 & 9 \\
10.Gramaniladari & 5 & 5 \\
\hline
\end{tabular}

The Church / Father RC was ranked secondly based on the benefits while interaction with fishers was first. The listed benefits were advice to improvement of mental health, solving some conflicts which raised due to distractive fisheries, subsidies for fisheries families who affected from destruction. The meantime, women welfare society provided the following services, especially when the people who affected from any incidents they provided resources for temporary transformation from fisheries like rotational loan services, training/motivation for selfemployment (Palmyra value added product, ornamental plants) and subsidies for widow's families (money for building a new well).

The government banks, community centers, government redevelopment project (GDP) and rural development society supported people in terms of loan facilities and other alternative employment opportunities. NEVI, police station, Samurdhi bank, school and public health instructor did their defined responsibilities. Essentially, Gramaniladhari, elder's development society, sports club, and school development society involved in other social activities too. To that, Gramaniladhari 
recommended to save natural resources of the village and cleaning the beach environment. Elder's development society facilitated pension for elders, subsidies for funerals, organized entertainment/sports programs for elders. Meanwhile, Sports club contributed a donation of money for affected fishermen, and they had a prominent hand to keep the village peace when anything disturbed the peace of the village.

Two-third of survey respondents experienced in fishing more than 10 years stated that destructive fishing activities were already used when their initial stage of fishing career. Meanwhile $85 \%$ of structure interviewed fishers said that a series of locally driven sensitization and awareness-raising activities were spearheaded by village leaders to reduce destructive fishing activities over the last 10-20 years while only $3 \%$ of survey respondents reported they could receive information and training with respect to other destructive fishing activities. ON the other hand, almost all key informants agreed that all fishing activities should be non-destructive. When author asked why they thought destructive fishing activities were reoccurring when every fisher was aware of its affects, these key informants said that it was only another malpractice in the society (like cattle robbery), which required a case-by-case solution and should not be generalized to all fishers.

The study revealed that local people were willing to report events on destructive fishing activities, government officials where they failed to report to ensure a timely flow of information and subsequent actions. $32 \%$ of the semi-structured interviews proved that it was extremely difficult for local fishers to locate these agents. Furthermore, sometimes people voluntarily took the task to monitor destructive fishing activities and report them to the responsible authorities. Finally, the complained people were seriously threatened by the fishers who were practicing destructive fishing activities. Interview results indicated that while many fishers were aware of the effects of destructive fishing activities, they thought it difficult to report about the engaged people because they felt they would not be protected. Indeed, if the perpetrators had a close relation with influential people in their communities then they could not 
easily be punished in accordance with current legal mechanisms and institutions.

\section{Conclusion}

Destructive fishing practices were widely practiced in the Pesalai. These practices were a major source of battles among the fishermen. There are fisheries instead of adopting the policy like Fisheries and Aquatic Resources Act 1996, have been using illegal techniques. The trawling net fishing, dynamite fishing, brush pile fishing and stake net were being used extensively by the fishers. However, the use of such gears has facilitated to catch more fish and earning high income. Resultant, the major negative impacts were gearing damages, nets damages and net loss. It is apparently found that, the majority of fisheries (93\%) had faith in fisher community organizations (fisheries co-op society, the church/father and women welfare society) in terms of resolving conflicts which were raised by destructive fisheries (wrangling, argument and dissension) while $7 \%$ of the respondents have faith in the state to resolve conflicts. The fisheries believed that the government supports for fishing activities was not well required. In addition, low level of awareness on the impacts of destructive fishing practices. The cost of enforcing the law is high and enforcement officers did not have proper knowledge of existing rules and regulations, other conservationists said that political influence has played a part in the non-implementation of such enforcing units. Hence, it is recommended that an awareness program should be organized to enlighten the net users of the negative consequences of the use of such methods. Regulations should be enforced, as a joint effort between the Fisheries Department and fisheries community organizations.

\section{Conflicts of Interest}

The authors declare no conflicts of interest.

\section{Acknowledgment}

My sincere gratitude to my advisor Prof. Oscar Amarasinghe for the continuous support of my research study and related research. 


\section{References}

[1] S. S. M. Peramunagama, O. Amarasinghe, K.C. Dinushika, A. D. Jayasinghe, R. Srikrishnan, A. Thileepan. Dissent on fisheries development; use of destructive fishing practices in Northern Sri Lanka. The proceeding of 9th MARE Conference People and the Sea, University of Amsterdam, Netherlands. 2017

[2] P. S. Asha, B. Johnson, L. Ranjith, E. Vivekanandan, C. S. Subin, M. S. Mohamed. Status of sea cucumber resources and impact of fishing ban on the livelihood of fishers in Gulf of Mannar and Palk Bay. Marine Fisheries Information Service; Technical and Extension Series. 2015, 226, 3-9.

[3] S. S. M. Peramunagama, O. Amarasinghe, M. A. M. I. Perera, K. H. K. L. Piyasiri. Use of destructive fishing gears in the North of Sri Lanka: A bottom-up analysis using participatory tools. The proceeding of 13th Academic sessions. university of Ruhuna, Sri Lanka. 2016.

[4] S. S. M. Peramunagama, R. Thusyanthini. Exploring the wellbeing factors and pathways for improving the wellbeing of Mannar fishing populations of Sri Lanka. National aquatic resources research and development agency (NARA) scientific session. 2019.

[5] K. Sivasubramaniam. Sri Lanka Fisheries Resources Development and Management in the Past. Asian Development Bank, Colombo.1995.

[6] S. A. Soosai, K. Stokke. Fisheries under fire, Impacts of war and challenges of reconstruction and development in Jaffna fisheries, Sri Lanka. Norsk Geografisk Tidsskrift-Norwegian Journal of Geography. 2006, 60, 240-248.

[7] C. G. Lundin, O. Linden. Coastal ecosystems: attempts to manage a threatened resource. Ambio. 1993, 468-473.

[8] U. S. Amarasinghe, M. D. Amarasinghe, C. Nissanka. Investigation of the Negombo estuary (Sri Lanka) brush park fishery, with an emphasis on community-based management. Fisheries Management and Ecology. 2002, 9, 41-56.

[9] V. Vivekanandan, H. M. Kasim. Identification and characterization of fisheries management units. Project in Tamil-nadu and Puducherry, India. 2011.

[10] J. Scholtens. The elusive quest for access and collective action: North Sri Lankan fishers' thwarted struggles against a foreign trawler fleet. International Journal of the Commons. 2016, 10, 929-952.

[11] M. C. Ohman, A. Rajasuriya, E, Olafsson. Reef fish assemblages in north-western Sri Lanka: distribution patterns and influences of fishing practises. Environmental Biology of Fishes. 1997, 49, 45-61.

[12] S. S. M.Peramunagama. Implications of technological change in a multi stakeholder fishery for fisheries development and livelihoods: The case of smallscale fisheries in the north of Sri Lanka. M.Phil dissertation. Faculty of Agriculture, University of Ruhuna, Matara, Sri Lanka. 2021. 